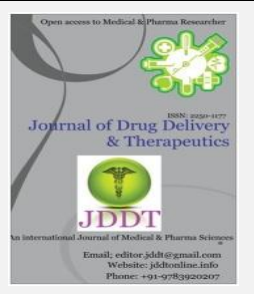

Open $\odot$ Access

Research Article

\title{
Simultaneous estimation of gabapentin and methylcobalamin in bulk and pharmaceutical dosage form by RP-HPLC
}

\section{Anjali Bakshi*, Monika K, Shweta Bhutada, Dr. M. Bhagvan Raju}

Department of Pharmaceutical Analysis and Quality Assurance, Sri Venkateshwara College of Pharmacy, Osmania University, Hyderabad 500081.

\begin{abstract}
A simple, selective, linear, precise, and accurate RP-HPLC method was developed and validated for the simultaneous estimation of Gabapentin \& Methylcobalamin from bulk and formulation. Chromatographic separation was achieved Isocratically on an Inertsil C18 column (150x4.6, $5 \mu$ particle size) using a mobile phase Buffer: Acetonitrile in the ratio of 60:40 v/v. The flow rate was $1.0 \mathrm{ml} / \mathrm{min}$, effluents were detected at $264 \mathrm{~nm}$ and $10 \mu \mathrm{l}$ of sample was injected. Retention time of Gabapentin \& Methylcobalamin was found to be 2.7 and 4.13 min respectively. Linearity of the method was in the concentration range of 25-150 $\mu \mathrm{g}$ for Gabapentin \& $0.125-0.750 \mu \mathrm{g}$ for Methylcobalamin. Percent recoveries obtained for both the drugs were $100.00 \%$. The percentage RSD for precision of the method was found to be less than $2 \%$. The method was validated according to the ICH guidelines. The method developed was successfully applied for the analysis of simultaneous estimation of Gabapentin \& Methylcobalamin tablets and was fairly good in comparison with other methods.
\end{abstract}

Keywords: Gabapentin, Methylcobalamin, HPLC.

Article Info: Received 24 Nov 2018; Review Completed 04 Jan 2019; Accepted 06 Jan 2019; Available online 15 Jan 2019

\section{Cite this article as:}

Bakshi A, Monika K, Bhutada S, Bhagvan Raju M, Simultaneous estimation of gabapentin and methylcobalamin in bulk and pharmaceutical dosage form by RP-HPLC, Journal of Drug Delivery and Therapeutics. 2019; 9(1):170-174 DOI: http://dx.doi.org/10.22270/jddt.v9i1.2204

*Address for Correspondence:

Anjali Bakshi, Department of Pharmaceutical Analysis and Quality Assurance, Sri Venkateshwara College of Pharmacy, Osmania University, Hyderabad -500081.

\section{INTRODUCTION}

Gabapentin is (Figure 1) is 1-(amino methyl) cyclo hexane acetic acid. It is an anticonvulsant drug for neuropathic pain and adjunct for seizures. It can be used in generalized anxiety disorders. Methylcobalamin (Figure 2$)$ is $\alpha-(5,6$ dimethyl benzimidazol) cobalmid cyanide $(3+)$. It is a form of Vit-B12.It is a water soluble vitamin with a key role in the normal functioning of brain, and nervous system. It has been shown to protect those who take it from neurological conditions and ageing in a way that it makes different from other drugs or therapy ${ }^{1-4}$.

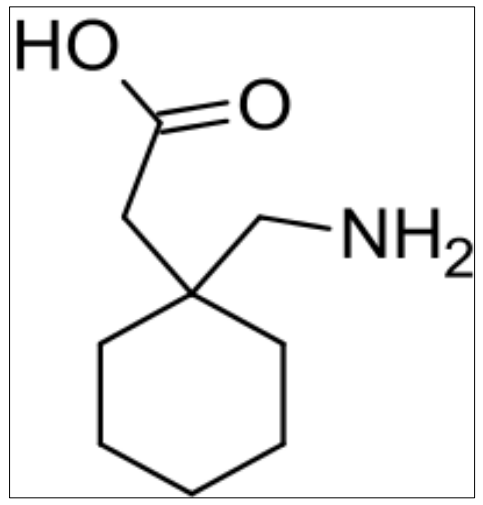

Figure 1: Gabapentin

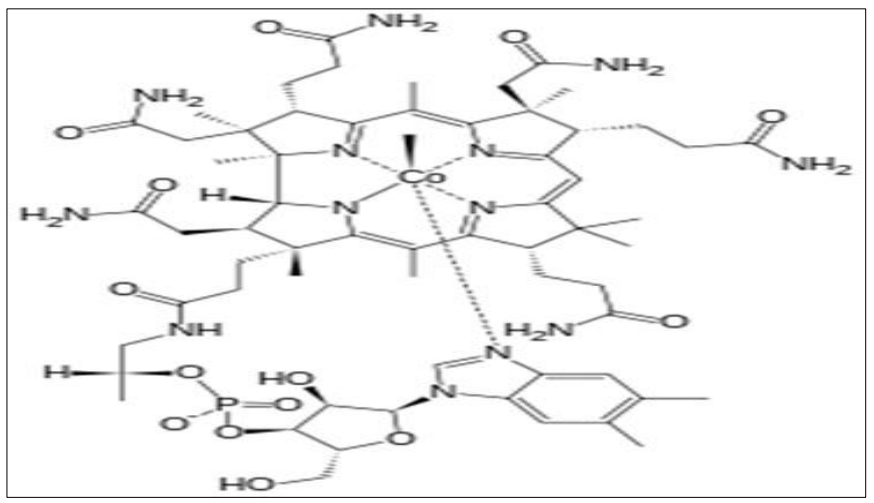

Figure 2: Methylcobalamin 
Literature survey revealed HPTLC, UV HPLC methods for the estimation of Gabapentin and Methylcobalamin. The present study aims to develop simple, accurate, precise and selective RP-HPLC assay procedure for the analysis of Gabapentin and Methylcobalamin in bulk drug samples and in combined dosage. The method is optimized and validated as per the International conference on Harmonization (ICH) guidelines.

\section{MATERIALS AND METHODS 5 -11}

Gabapentin (GABA), Methylcobalamine (MECO) and Chemicals were obtained as a sample from Bio-Leo Analytical Labs private Ltd with the percentage purity of $99.1 \%$ and $99.7 \%$, respectively. A commercial tablet formulation Gabantin Plus ${ }^{\circledR}$ from Sun Parma (Mumbai,

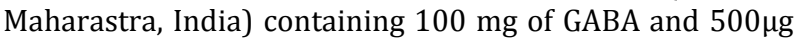
of MECO was purchased from local market and used within their shelf life period. HPLC grade acetonitrile was obtained from Merck Limited. Analytical grade Buffer obtained from SD Fine (Mumbai, India). HPLC grade water was obtained by distilling deionizer water produced by a Milli-Q Millipore water system (Milford, MA, USA). All other chemicals used were of pharmaceutical or analytical grade.

\section{Preparation of mobile phase:}

Mixture of Buffer and Acetonitrile (60:40 ratios) was sonicated and the resulting solution was degassed by vacuum filtration through 0.4 micron membrane filter.

\section{Preparation of standard stock solutions:}

Gabapentin working standard $100 \mathrm{mg}$ was weighed and transferred along with 0.5 of $\mathrm{mg}$ of Methylcobalamine working standard into $100 \mathrm{ml}$ volumetric flask, diluent was added for making up volume. The resultant solution was sonicated.

\section{Standard preparation:}

One ml of standard stock solution was transferred into 10 $\mathrm{ml}$ volumetric flask and diluted to volume with diluent.

\section{Preparation of sample solution:}

Pre weighed 20 Tablets were finely triturated. Finely grinded sample quantitatively equivalent to $100 \mathrm{mg}$ of Gabapentin and $0.5 \mathrm{mg}$ of Methylcobalamine was transferred into $10 \mathrm{ml}$ volumetric flask; $25 \mathrm{ml}$ of diluents was added. The resultant was sonicated for 10 minutes and diluted to volume with diluent. Further the solution was filtered through filter paper. Ten $\mathrm{ml}$ of filtrate was diluted to $100 \mathrm{ml}$ with mobile phase.

\section{Method development:}

After various trials, the following chromatographic conditions were finally optimized for the simultaneous estimation of Gabapentin \& Methylcobalamine in a tablet dosage form. Mobile phase constitutes of Buffer: Acetonirile in the ratio of $60: 40 \mathrm{v} / \mathrm{v}$. Detection wave length $264 \mathrm{~nm}$ flow rate $1.0 \mathrm{ml} / \mathrm{min}$, after a steady baseline the standard solution were injected and chromatograms were recorded until the reproducibility of the peak areas were found and finally $100 \mu \mathrm{g} / \mathrm{ml}$ of the standard solution of the individual samples of Gabapentin and Methylcobalamine and mixed standard solutions were injected and the chromatograms were recorded. The separation of Gabapentin and Methylcobalamine was observed with retention times of 2.7 and $4.13 \mathrm{~min}$ respectively. The typical chromatograms of the standard solutions were recorded for the repeatability and the respective chromatogram was given in Figure 3.

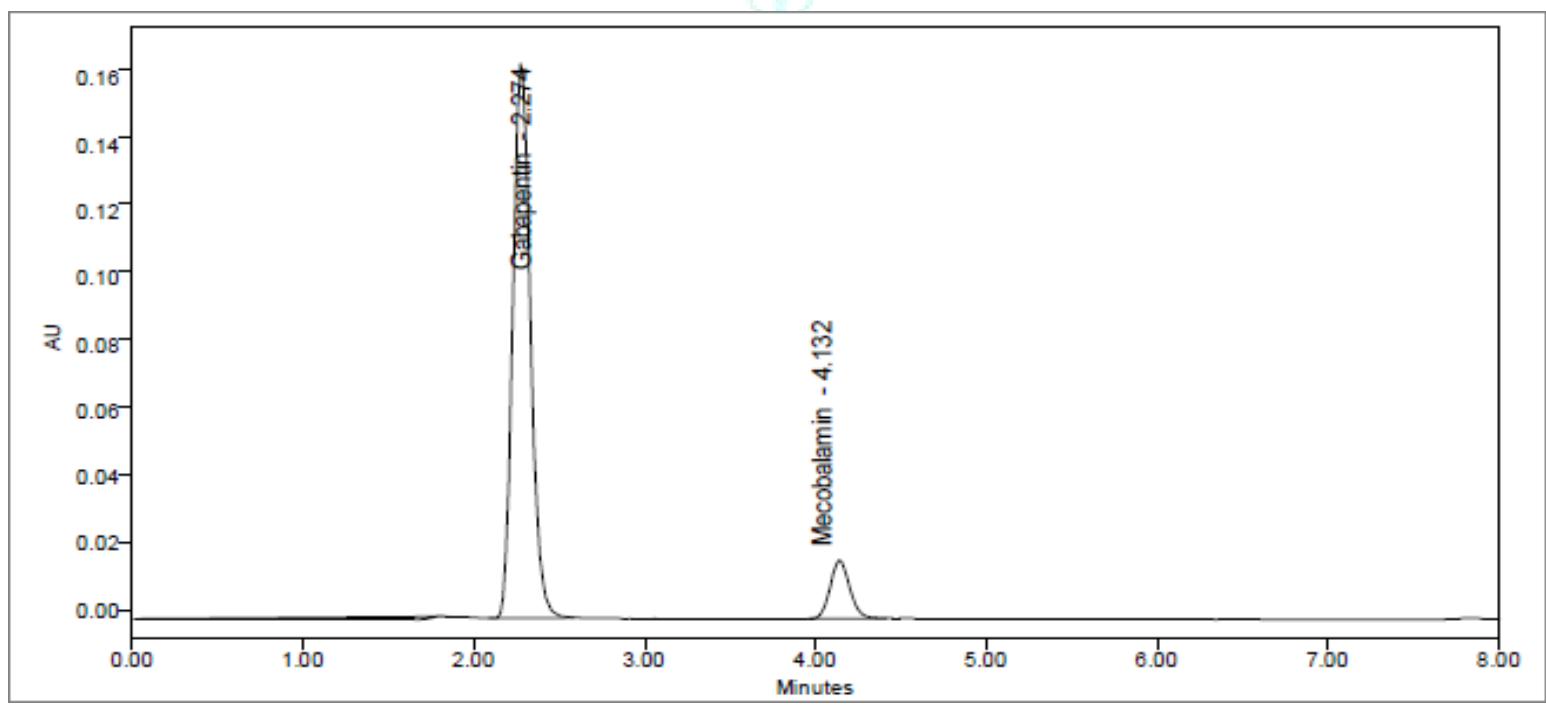

Figure 3: Typical chromatogram of Gabapentin and Methylcobalamine detection at 264nm.

\section{Method validation:}

The proposed method was validated as per ICH guidelines.

System suitability data for Gabapentin and Methylcobalamin

\begin{tabular}{|l|l|l|l|l|l|}
\hline SR .No & Peak Name & $\begin{array}{l}\text { Retention } \\
\text { Time }\end{array}$ & Area & $\begin{array}{l}\text { Plate } \\
\text { Count }\end{array}$ & $\begin{array}{l}\text { USP } \\
\text { Tailing }\end{array}$ \\
\hline 1 & Gabapentin & 2.274 & 1173835 & 3345 & 1.15 \\
\hline 2 & Methylcobalamin & 4.132 & 136983 & 6228 & 1.11 \\
\hline
\end{tabular}




\section{Precision:}

The precision of the method verified by repeatability and by intermediate precision. Repeatability was checked by injecting six individual preparations of Gabapentin and Methylcobalamin real sample (tablets). The intermediate precision of the method was also evaluated using different analyst and performing the analysis on different days.
Precision of assay method was evaluated by carrying out six independent assays of real sample of Gabapentin and Methylcobalamin at $100 \mu \mathrm{g} / \mathrm{ml}$ level against qualified reference standard. The intermediate precision of the assay method was evaluated by different analysts by making use of different columns and different lot of the sample.

Table 1: System Precision Study Results:

\begin{tabular}{|l|l|l|}
\hline Name & Gabapentin & Methylcobalamin \\
\hline Injection-1 & 1179101 & 136890 \\
\hline Injection -2 & 1173310 & 136556 \\
\hline Injection -3 & 1176860 & 136884 \\
\hline Injection -4 & 1177331 & 136415 \\
\hline Injection -5 & 1182173 & 136967 \\
\hline Injection -6 & 1188341 & 135452 \\
\hline Mean & 1179519 & 136527 \\
\hline Standard deviation & 5204.9 & 569.53 \\
\hline \% RSD & 0.441 & 0.42 \\
\hline
\end{tabular}

Table 2: Method Precision Study Results:

\begin{tabular}{|l|l|l|}
\hline Name & Gabapentin & Methylcobalamin \\
\hline Injection-1 & 1187345 & 136875 \\
\hline Injection -2 & 1180165 & 138974 \\
\hline Injection -3 & 1189456 & 136888 \\
\hline Injection -4 & 1178144 & 138565 \\
\hline Injection -5 & 1178345 & 137145 \\
\hline Injection -6 & 1181122 & 138788 \\
\hline Mean & 1182430 & 137873 \\
\hline Standard deviation & 4804.6 & 1002.45 \\
\hline \% RSD & 0.406 & 0.73 \\
\hline
\end{tabular}

\section{Linearity:}

The linearity range was found to be from $25 \mu \mathrm{g}$ to $150 \mu \mathrm{g}$ for Gabapentin and $0.125 \mu \mathrm{g}$ to $0.75 \mu \mathrm{g}$ for Methylcobalamin.

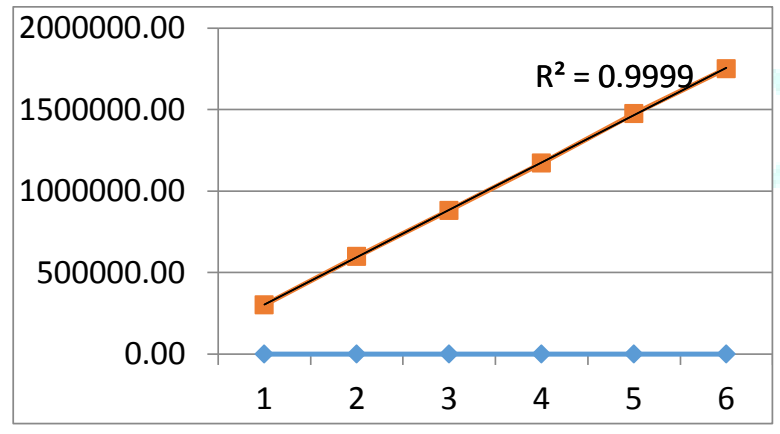

Figure 4: Linearity of Gabapentin

\section{Accuracy:}

Accuracy of the assay method was evaluated in triplicate using three concentration levels 80,100 and $120 \mu \mathrm{g} / \mathrm{ml}$ on real sample (tablets). Standard addition and recovery

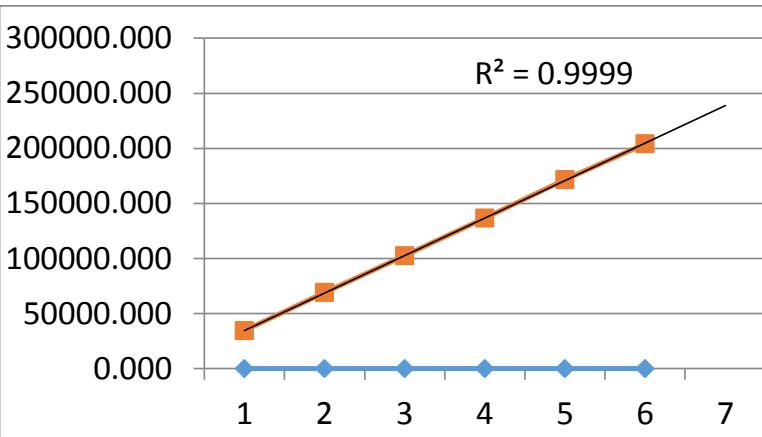

Figure 5: Linearity of Mecobalamine

experiments were conducted on real sample to determine accuracy the method. Study was carried out in triplicate using three $(80,100$ and $120 \%)$ concentration levels. The percentages of recoveries for Gabapentin and Methylcobalamin were calculated.

Table 3: Accuracy data for Gabapentin:

\begin{tabular}{|l|l|l|l|l|l|}
\hline $\begin{array}{l}\text { \% Concentration } \\
\text { (at } \begin{array}{c}\text { Area } \\
\text { level) }\end{array}\end{array}$ & $\begin{array}{l}\text { Amount Added } \\
\text { (mg) }\end{array}$ & $\begin{array}{l}\text { Amount found } \\
\text { (mg) }\end{array}$ & $\begin{array}{l}\text { \% } \\
\text { Recovery }\end{array}$ & $\begin{array}{l}\text { Mean } \\
\text { Recovery }\end{array}$ \\
\hline $80 \%$ & 924479 & 80.00 & 78.76 & 98.45 & \multirow{2}{*}{99.09} \\
\hline $100 \%$ & 1168610 & 100.00 & 99.55 & 99.55 & \\
\hline $120 \%$ & 1398264 & 120.00 & 119.12 & 99.27 & \\
\hline
\end{tabular}


Table 4: Accuracy data for Methylcobalamin:

\begin{tabular}{|c|c|c|c|c|c|}
\hline $\begin{array}{l}\% \text { Concentration (at } \\
\text { specification level) }\end{array}$ & Area & $\begin{array}{l}\text { Amount Added } \\
\text { (mg) }\end{array}$ & $\begin{array}{l}\text { Amount found } \\
\text { (mg) }\end{array}$ & $\begin{array}{l}\% \\
\text { Recovery }\end{array}$ & $\begin{array}{l}\text { Mean } \\
\text { Recovery }\end{array}$ \\
\hline $80 \%$ & 110498 & 0.40 & 0.40 & 100.83 & \multirow{3}{*}{99.93} \\
\hline $100 \%$ & 136596 & 0.50 & 0.50 & 99.72 & \\
\hline $120 \%$ & 163137 & 0.60 & 0.60 & 99.24 & \\
\hline
\end{tabular}

Table.5: LOD of Gabapentin and Methylcobalamin:

\begin{tabular}{|l|l|l|}
\hline Parameters & Gabapentin & Methylcobalamin \\
\hline Slope & 19494 & 10926 \\
\hline Intercept $(\mathrm{C})$ & 4627 & 487.5 \\
\hline LOD $(\mu \mathrm{g} / \mathrm{ml})$ & 0.78 & 0.15 \\
\hline
\end{tabular}

Table 6: LOQ of Gabapentin and Methylcobalamin:

\begin{tabular}{|l|l|l|}
\hline Parameters & Gabapentin & Methylcobalamin \\
\hline Slope & 194943 & 10926 \\
\hline Intercept $(\mathrm{C})$ & 4627 & 487.5 \\
\hline LOQ $(\mu \mathrm{g} / \mathrm{ml})$ & 2.73 & 0.45 \\
\hline
\end{tabular}

\section{Robustness:}

To determine the robustness of the developed method, experimental conditions were deliberately altered and the system suitability parameters were evaluated. Tailing factor for Gabapentin and Methylcobalamin was recorded.
The flow rate of the mobile phase was $1.0 \mathrm{ml} / \mathrm{min}$, to study the effect of flow rate on the retention time; flow was changed by \pm 0.2 units from 0.8 to $1.2 \mathrm{ml} / \mathrm{min}$. The effect of the column temperature on retention time was studied at $30 \stackrel{\circ}{\circ}$.

Table 7: Robustness data for Gabapentin and Methylcobalamin:

\begin{tabular}{|l|l|l|l|l|}
\hline & \multicolumn{2}{|l|}{ Gabapentin } & \multicolumn{2}{l|}{ Methylcobalamin } \\
\hline & Retention Time & Theoretical Plate no & Retention Time & Theoretical Plate no \\
\hline Flow rate- $0.8 \mathrm{ml}$ & 2.00 & 3043043 & 3.363 & 2137383 \\
\hline Flow rate- $1.2 \mathrm{ml}$ & 2.368 & 2413944 & 4.813 & 1688920 \\
\hline Temperature $-25^{\circ} \mathrm{C}$ & 2.261 & 2755918 & 4.157 & 1932082 \\
\hline Temperature- $35^{\circ} \mathrm{C}$ & 2.273 & 2970931 & 4.323 & 1945900 \\
\hline
\end{tabular}

Table 8: Comparison table:

\begin{tabular}{|c|c|c|c|c|c|c|}
\hline \multicolumn{7}{|c|}{ CROMATOGRAPHIC CONDITIONS } \\
\hline & \multicolumn{2}{|c|}{ Method Developed } & \multicolumn{2}{|c|}{$\underline{R E F 10}$} & \multicolumn{2}{|l|}{ REF 11} \\
\hline HPLC system & \multicolumn{2}{|c|}{ WATERS E 2695} & \multicolumn{2}{|c|}{ WATERS 515 pump } & \multicolumn{2}{|c|}{ WATERS E 2695} \\
\hline Detector & \multicolumn{2}{|l|}{ PDA } & \multicolumn{2}{|c|}{ PDA } & \multicolumn{2}{|c|}{ PDA } \\
\hline Column & \multicolumn{2}{|c|}{$\begin{array}{l}\text { C } 18 \\
(150 \times 4.6 \mathrm{~mm} \times 5 \mu \mathrm{m})\end{array}$} & \multicolumn{2}{|l|}{ C 18} & \multicolumn{2}{|c|}{$\begin{array}{l}\text { C } 18 \\
(250 \times 4.6 \mathrm{mmx} 5 \mu \mathrm{m})\end{array}$} \\
\hline Temperature & \multicolumn{2}{|c|}{$30^{\circ} \mathrm{C}$} & \multicolumn{2}{|l|}{ Room Temp. } & \multicolumn{2}{|c|}{$30^{\circ} \mathrm{C}$} \\
\hline Elution & \multicolumn{2}{|l|}{ Isocratic } & \multicolumn{2}{|l|}{ Isocratic } & \multicolumn{2}{|l|}{ Isocratic } \\
\hline Mobile Phase & \multicolumn{2}{|l|}{$\begin{array}{l}\text { Buffer:CAN } \\
(60: 40)\end{array}$} & \multicolumn{2}{|l|}{$\begin{array}{l}0.1 \% \text { OPA:ACN } \\
(55: 45 \mathrm{v} / \mathrm{v})\end{array}$} & \multicolumn{2}{|l|}{$\begin{array}{l}\text { OPA :MEOH } \\
(50: 50 \mathrm{v} / \mathrm{v})\end{array}$} \\
\hline Flow Rate & \multicolumn{2}{|l|}{$1 \mathrm{ml} / \mathrm{min}$} & \multicolumn{2}{|l|}{$1 \mathrm{ml} / \mathrm{min}$} & \multicolumn{2}{|l|}{$0.8 \mathrm{ml} / \mathrm{min}$} \\
\hline Injection volume & \multicolumn{2}{|l|}{$10 \mu \mathrm{l}$} & \multicolumn{2}{|l|}{$10 \mu \mathrm{l}$} & \multicolumn{2}{|l|}{$10 \mu \mathrm{l}$} \\
\hline Wavelength & \multicolumn{2}{|l|}{$264 \mathrm{~nm}$} & \multicolumn{2}{|l|}{$271 \mathrm{~nm}$} & \multicolumn{2}{|l|}{$275 \mathrm{~nm}$} \\
\hline Run time & \multicolumn{2}{|l|}{$8 \min$} & \multicolumn{2}{|l|}{$5 \mathrm{~min}$} & \multicolumn{2}{|l|}{$6 \min$} \\
\hline \multicolumn{7}{|c|}{ SYSEM SUTABILITY PARAMETERS } \\
\hline & Method Devel & & REF 10 & & $\underline{R E F 11}$ & \\
\hline & GABA & MCOB & $\overline{\mathrm{GABA}}$ & MCOB & $\overline{\text { GABA }}$ & MCOB \\
\hline$R T(\min )$ & 2.7 & 4.13 & 2.5 & 3.08 & 2.896 & 4.459 \\
\hline$L O D(\mu g / m I)$ & 0.78 & 0.15 & 0.984 & 0.0068 & 2.83 & 2.44 \\
\hline$L O Q(\mu \mathrm{g} / \mathrm{ml})$ & 2.73 & 0.45 & 3.28 & 0.0226 & 9.46 & 8.16 \\
\hline Linearity $(\mu \mathrm{g} / \mathrm{ml})$ & $25-150$ & $0.125-0.750$ & $600-1800$ & $1-3$ & $50-150$ & $50-150$ \\
\hline Accuracy (\%) & $99.00-99.55$ & $99.24-100.83$ & $99.98-100.28$ & $\begin{array}{l}99.65 \\
100.38\end{array}$ & $\begin{array}{l}100.0 \\
100.0\end{array}$ & $\begin{array}{l}100.0 \\
100.0\end{array}$ \\
\hline Precision (\%RSD) & 0.15 & 0.21 & 0.13 & 0.13 & 0.34 & 0.13 \\
\hline
\end{tabular}




\section{CONCLUSION}

The present results provide clear evidence that the proposed method can be successfully used for simultaneous determination of drug content in marketed formulations.

\section{REFERENCES}

1) International Conference on Harmonization (ICH) of technical requirements for the registration of pharmaceuticals for human use, validation of analytical procedures: definitions and terminology, Geneva, 1996.

2) Sharma MC et al, Simultaneous Estimation and Validation of Gabapentin and Methylcobalamin in Tablet Dosage form: hydrotropic approach, Drug Invention Today, 2011; 3(6):95.

3) Baheti KG, Galande VR, Simultaneous Estimation of Gabapentin in the Presence of Methylcobalamin in Tablet by HPTLC Method, International journal of research in Pharmaceutical and Biomedical sciences, Jul-Sep 2011; 2(3).

4) Abdullatif HE, Khalil H.M., Colorimetric determination of Gabapentin in pharmaceutical formulation, J. Pharma. and Biomed. Anal, 2003.

5) Bharath BR, Shantha A., Malairajan P. et al. Simultaneous estimation and validation of Gabapentin and Methylcobalamin in combined dosage form by PR-HPLC, Indian Drugs, 2007; 44(10)L:784-788. 8. Beckett A. H. and Stenlake.
6) Galande R et al, UV VIS Spectrophotometric method for the estimation of Gabapentin \& Mecobalamin in bulk \& tablet, International Journal of Chemtech research, Jan - Mar 2010; 2(1):695-699

7) Lakshmi B et al, UV VIS Spectrophotometric method for the estimation of Gabapentin in formulations, The Experiment, August 2012; 2:84-92.

8) Goti PP, Patel PB, Development and validation of ratio derivative spectrophotometric method for simultaneous estimation of Gabapentin, Methylcobalamin and alpha lipoic acid in tablet formulation, Journal of Pharmacy research, june 2013; 6(6):

9) Saravanan V., Revathi R., Meera N. Method development and validation for the simultaneous estimation of lycopene and ubidecarenone by RP-HPLC in combined pharmaceutical dosage form. Journal of Drug Delivery and Therapeutics, 2016; 6(5):46-51.

10) Shashe Kumar P, Reddy $R$ et.al. RP-HPLC method development and validation for simultaneous estimation of gabapentin and mecobalamine in tablet dosage form. IJPRA, 2014; 4(7):388-392.

11) Sumaiya $H$, Vani $R$ et al, stability indicating method development and Validation of RP-HPLC method for simultaneous estimation of gabapentin and mecobalamine in bulk and its tablets; world journal of pharmacy and pharmaceutical sciences; 2014,3(12):1095-1106 